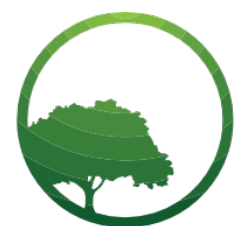

Business \& Social Science IJRBS

\section{Research in Business and Social Science}

IJRBS Vol 6 No 6, ISSN: 2147-4478

Contents available at www.ssbfnet.com/ojs

Doi: $10.20525 i j r b s . v 6 i 6.830$

\title{
Analysis of Dominant Factors in Improving Performance of Small Medium Industry in the Field Marine and Fishing Processing
}

\section{Edy Supriyadi}

Graduate School Pancasila University, Jakarta, Indonesia

\section{Iha Haryani Hatta}

Graduate School Pancasila University, Jakarta, Indonesia

\section{Darmansyah}

Graduate School Pancasila University, Jakarta, Indonesia

\section{Abstract}

The existence of global market resulted in the increasing number of business actors, especially Small and Medium Enterprises (SMEs). Currently SMEs are experiencing increasingly fierce market competition. Even the competition is in an increasingly complex condition. Faced with this condition, SMEs are required to have the ability to survive and improve its performance. The population of this research is the perpetrators of SMEs in the field of fishery and marine processing business in Lontar Village, Banten Province. The sample are participant of 46 SME actors. Technical sampling is purposive sampling. The data in this study is the primary data collected through questionnaires. The result are (1)Competence leader (KOM) has a positive influence on business performance variables (KIN) with a significant value of 0.070 at a significance level of 0.10.(2). Innovation (INO) has a positive influence on business performance variables (KIN) with a 0.000 significance level at a significant level of 0.05.(3). Entrepreneurship (WIRA) has a positive influence on business performance variables (KIN) with a synergy value of 0.00 at a significant level of 0.05.(4). Investment (INV) has no effect on business performance with significance of 0.223.(5). The moderator variables of entrepreneurs have an influence in contributing to the leadership competence of performance. With a significant value of 0.032.(6). The moderator variables of entrepreneurs have an influence in contributing to innovation on the performance of Entrepreneurship, with a significant value of 0.000 at the 0.05 level (7). The moderator variables of the entrepreneur have no influence in contributing to investment on the performance of the company. with a significant value of 0.060 at the 005 level.

Key Words : Entrepreneurship, Leadership Competence, Investment, Performance, JEL classification: C51, M15, M31 


\section{Introduction}

The existence of global market resulted in the increasing number of business actors, especially Small and Medium Enterprises (SMEs). Currently SMEs are experiencing increasingly fierce market competition. Even the competition is in an increasingly complex condition. Faced with this condition, SMEs are required to have the ability to survive and improve its performance.

SMEs should ensure that the costs incurred to run a business are not wasted. Through the additional investment is expected to increase business activities so that can be obtained profit in the future, which will ultimately improve the performance of SMEs.

Leadership plays a major role in the success of corporate strategy management. The role of leadership has an impact on the achievement of business performance as one of the determinants of success in achieving the vision, mission and goals of the organization. Therefore, in the effort to achieve maximum SME performance, it is necessary influence from the leadership of SMEs. According to Hughes et al (2015) leadership as a process of influencing an organized group to achieve group goals. In addition, the educational level of the leader also supports the success of corporate strategy management.

There are 3 (three) reasons underlying developing countries to view the importance of SMEs (Berry et al 2002). First is the performance of SMEs tend to be better in producing a productive workforce. Second, SMEs often achieve increased productivity through investment and technological change. Third, SMEs have an advantage in terms of flexibility rather than big business. SMEs can be said to have played an important role in absorbing the workforce, increasing the number of business units, and supporting the income of the community. In Indonesia, the SME sector is becoming a bigger pedestal of life, especially to create markets, develop trade, manage natural resources, reduce poverty and create jobs, both for small and medium enterprises (Tulus 2009).

Banten province has 2 regencies (Pandeglang and Serang districts) with a large number of Small and Medium Enterprises in the field of fisheries and marine. Fish processing includes fresh fish processing, canning, freezing, salting, drying, fumigation, fumigation, fermentation, reducing, semi and other processing. Furthermore, the business activities of fishery product processing in Banten Province are generally still dominated by small and medium scale enterprises with all the limitations, including: weak in capital, technology, innovation and information, management and marketing, is subsystem and spread partially.

\section{Literature Review}

An important requirement for the effectiveness or success of leaders (leadership) and managers (management) in assuming their respective roles, duties, functions, or responsibilities is competence. The concept of competence for the first time was popularized by Boyatzis (1982) defined competence as "the ability of a person who appears in his or her attitude in accordance with the needs of the work within the organization's environmental parameters and gives the desired result". Historically, the development of competence can be seen from several definitions of competency selected from time to time developed by Burgoyne (1988), Woodruffe (1990), Spencer et al. (1990), Furnham (1990) and Murphy (1993).

Investment is the attribution of sources in the long run to generate profits in the future (Mulyadi, 2001: 284). Investments can also be defined as investments or ownership of resources in the long 
term that will be useful in some future accounting periods (Supriyono 1987: 424). Investment can also be defined as the placement of the current amount of funds in the hope of making a profit in the future (Halim, 2003: 2).

Generally investment can be divided into two, namely (Halim, 2003: 2):

1. Invest in financial assets

Investment in financial assets can be divided into 2 , namely:

a. Investments in financial assets conducted in the money market, for example in the form of certificates of deposit, commercial paper, money market securities and others.

b. Investments in financial assets conducted in the capital market, such as stocks, bonds, warrants, options and more.

2. Investing in real assets

Investments in real assets are realized in the form of productive asset purchases, factory establishment, mining opening, plantation opening and others.

According to Yogi in LAN (2007: 115), innovation is usually closely related to a dynamic and growing environment. Understanding innovation itself is very diverse, and from many perspectives. According to Rogers in LAN (2007: 115) explains that innovation is an idea, practice, or object that is considered new by the individual one unit of other adoption. Meanwhile, according to Damanpour that an innovation can be a new product or service, new product process technology, new structural and administrative systems or new plans for members of the organization.

Business performance is a measure of achievement gained from the overall business activity process of a company (Best 2009). Business performance is an indication of the advanced depiction of a company (Doyle 2006). Business performance includes: profit rate, sales volume, market share and customer satisfaction level.

I. The rate of profit represents the difference between the realized revenue arising from transactions during a period and the costs associated with the income.

II. Sales volume is goods sold in the form of money for a certain period and in it has a good service strategy.

III. Market share can be interpreted as part of the market that is controlled by a company, or the percentage of sales of a company to total sales of the largest competitors at a certain time and place.

IV. The level of customer satisfaction is the level of one's marketing after comparing the performance of the product he feels with his expectations

Company performance is a full view of the company over a certain period of time, is the result or achievement that is influenced by the company's operational activities in utilizing resources owned. Performance is a term generally used for some or all actions or activities of an organization for a period with reference to standard amounts such as past or projected cost costs, on the basis of efficiency, accountability or accountability of management and the like (Srimindarti, 2004).

Understanding Entrepreneurship comes from the French language, the intermediary. Some sense of entrepreneurship are:

I. Entrepreneurship is a value embodied in the behavior that is used as the basis of resources, driving force, goals, strategies, tips, processes and business results (Achmad Sanusi, 2008). 
II. Entrepreneurship is a process of applying creativity and innovation in solving problems and finding opportunities to improve life. (Zimmerer, 2008).

III. Entrepreneurship is the spirit, attitude, behavior, and ability of a person in dealing with a business or activity that leads to searching, creating and implementing new ways of working, technology and products by improving efficiency in order to provide better services and / or obtain profits greater than. (Decree of the Minister of Cooperatives and Development of Small Enterprises Number 961 / KEP / M / XI / 1995).

\section{Research and Methodology}

\section{Statement of The Problem}

1. Is there influence of leadership competence, Investment, Innovation, entrepreneurship partially to Business Performance?

2. Is there any influence of entrepreneurship knowledge in encouraging business performance from the point of competence of leadership, innovation and investment?

3. What are the constraints faced by MSMEs?

\section{Research Objectives}

1. To know the influence of leadership competence, Inevstasi, Innovation, entrepreneurship partially to Business Performance

2. To know the influence pengatahuan entrepreneur in encouraging business performance from the angle of leadership competence, innovation and investment

3. To know the constraints faced by the perpetrators of SMEs

\section{Questionnaire Development}

\section{Population and Sample}

The population of this research is the perpetrators of SMEs in the field of fishery and marine processing business in Lontar Village, Tirtayasa District, Serang Regency, Banten Province. The sample is a marketing management and innovation management participant of $46 \mathrm{SME}$ actors. Technical sampling is purposive sampling.

\section{Operational Variable}

The data in this study is the primary data collected through questionnaires. Questionnaire on leadership competence, business investment and business performance using ordinal scale.

\section{Analysis}

\section{Multiple Regression Analysis}

To know the influence of independent variable to dependent variable, then multiple linear regression test Used.

Classical Assumption Testing

1. Normality Test

2. Heteroscadastic Test 
3. Mulyicolinearity Test

4. Autocorrelation Test

\section{Hyphothesis Testing}

1. There is no effect of Leadership Competence on Business Performance of SMES

2. There is no effect of Innovation on Business Performance of SMEs

3. There is no effect of Knowledge Entrepreneurship to Business Performance of SMES

4. There is no effect of Leadership Competence on Business Performance of SMEs with moderated entrepreneur knowledge..

5. There is no effect of Innovation on Business Performance SMEs moderated illmu entrepreneurship chapters.

6. There is no effect of Entrepreneurship Knowledge on Business Performance of SMEs moderated entrepreneurial knowledge.

\section{Findings}

\section{Multiple Regression Analysis}

To know the influence of independent variable to dependent variable, then multiple linear regression test.

\section{Classical Assumption Testing}

1) Normality Test

The purpose of the normality test is to find out whether the distribution of a data follows or approaches the normal distribution, Situmorang et al (2008: 55).

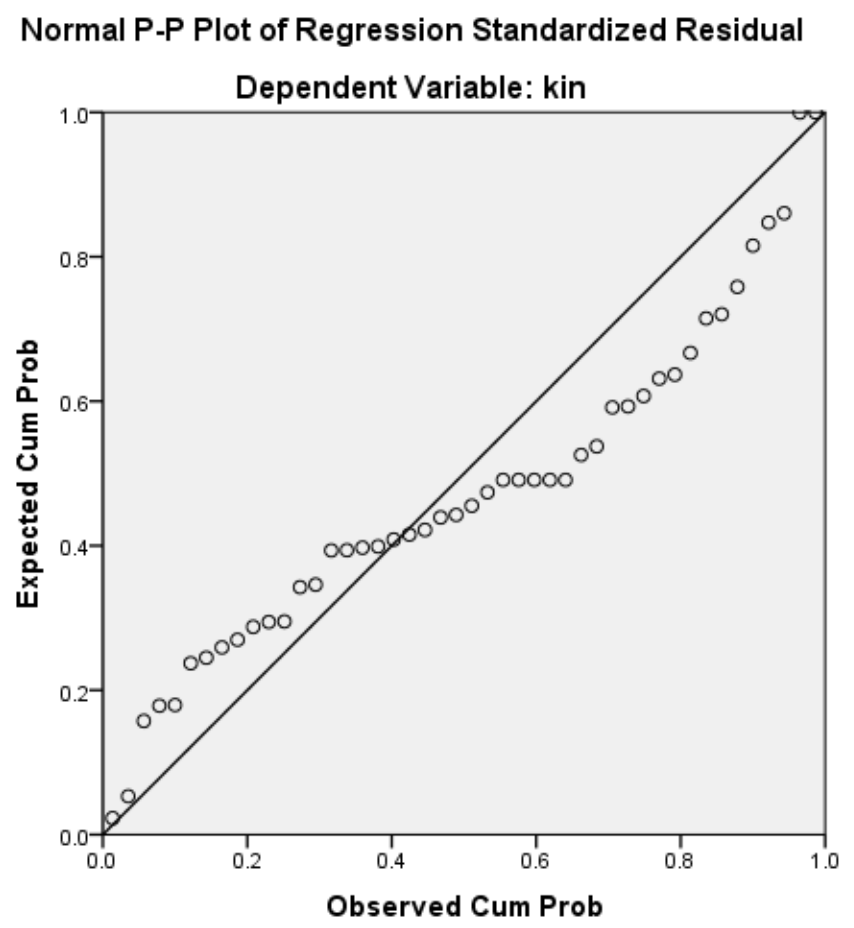


Figure 1: Normal P-P Plot Regression Standardized Residual

In Figure 1, it can be seen that the data (dots) spreads around the diagonal line and follows the direction of the diagonal line. Therefore, based on Figure 1 it can be concluded that it has met the normality test.

2) Heteroscedasticity Test

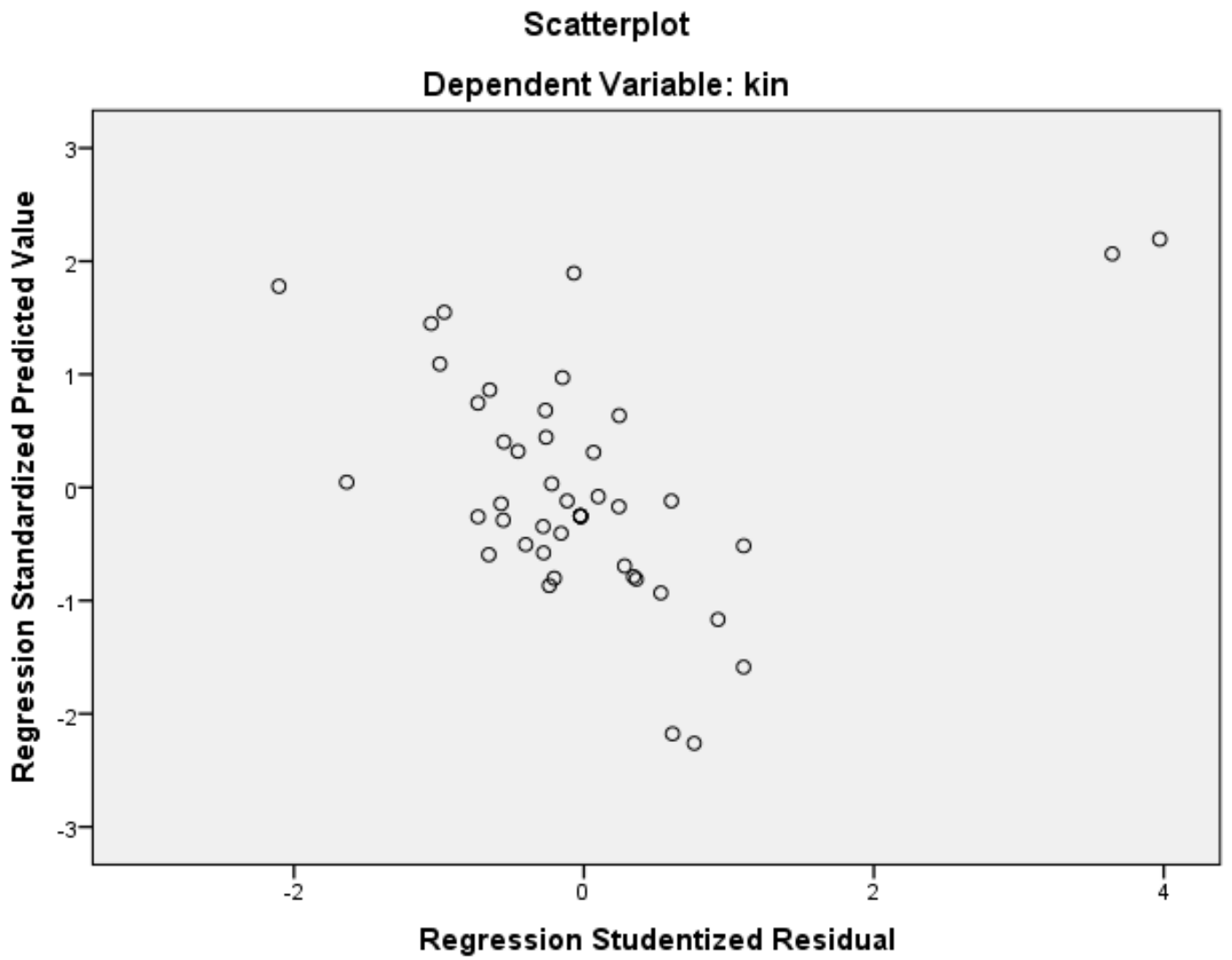

Figure 2: Scatterplot

In Figure 2. it can be seen that the scatter diagram does not form a certain pattern because it does not experience interference heteroskedastisitas.

3) Multicolinearity test

Tabel 2: Hasil Uji Multikolinieritas

\begin{tabular}{|c|c|c|c|c|c|c|c|}
\hline \multirow{2}{*}{\multicolumn{2}{|c|}{ Model }} & \multicolumn{2}{|c|}{$\begin{array}{l}\text { Unstandardized } \\
\text { Coefficients }\end{array}$} & \multirow[b]{2}{*}{$\mathrm{t}$} & \multirow[b]{2}{*}{ Sig. } & \multicolumn{2}{|c|}{ Collinearity Statistics } \\
\hline & & B & Std. Error & & & Tolerance & VIF \\
\hline 1 & (Constant) & -4.424 & 14.726 & -.300 & .765 & & \\
\hline & Kom & -.771 & .432 & -1.785 & .081 & .786 & 1.272 \\
\hline & Inv & 1.494 & .411 & 3.631 & .001 & .708 & 1.413 \\
\hline & Ino & 1.004 & .756 & 1.328 & 191 & .887 & 1.127 \\
\hline
\end{tabular}

In Table 2. explains the amount of VIF for each independent variable. All independent variables have VIF values $<10$, so it can be concluded that the multicollinearity problem does not exist. 
4). Autocorrelation

Tabel 3: Durbin Watson Result

Model Summary

\begin{tabular}{|l|l|l|l|l|l|}
\hline Model & $R$ & $R$ Square & $\begin{array}{l}\text { Adjusted } \\
\text { Square }\end{array}$ & $\begin{array}{l}\text { Rtd. Error of } \\
\text { the Estimate }\end{array}$ & Watson- \\
\hline 1 & $.569^{\mathrm{a}}$ & .324 & .275 & 12.92260 & 2.321 \\
\hline
\end{tabular}

a. Predictors: (Constant), ino, kom, inv

b. Dependent Variable: kin

The DW test value lies between du and 4-du $(1.6678<2.321<(2.3400)$, which means that the DW test value is located in a non autocorrelation area, so it can be said that the model used no autocorrelation.

\section{Regression Analysis}

Table 4: Results of Multiple Linear Regression Test with

Variable Moderator Entrepreneurship

\begin{tabular}{|c|c|c|c|c|c|}
\hline \multirow[b]{2}{*}{ Mod } & & \multicolumn{2}{|c|}{ Unstandardized Coefficients } & \multirow[b]{2}{*}{$\mathrm{t}$} & \multirow[b]{2}{*}{ Sig. } \\
\hline & & $\mathrm{B}$ & Std. Error & & \\
\hline \multirow[t]{8}{*}{1} & (Constant) & -327.025 & 73.505 & -4.449 & .000 \\
\hline & Kom & 5.186 & 2.821 & 1.839 & .074 \\
\hline & Inv & -3.174 & 2.564 & -1.238 & .223 \\
\hline & ino & 18.397 & 4.647 & 3.959 & .000 \\
\hline & wira & 21.925 & 4.840 & 4.530 & .000 \\
\hline & kom_w & -.395 & .178 & -2.224 & .032 \\
\hline & inv_w & .289 & .149 & 1.937 & .060 \\
\hline & ino_w & -1.158 & .297 & -3.903 & .000 \\
\hline
\end{tabular}

Dependent Variable: kin

Dependent Variable: kin

KOM: Leadership Competencies

INV: Investment

INO: Innovation

WIRA: Entrepreneurship

KIN: Business Performance

Based on the results of the above data, multiple linear regression equation obtained in this study are:

$\mathrm{KIN}=-327.0,025+5.186$ X1 - 3.174 7 X2 + 18.397 X3 + 21.925 WIRA-0..95 KOM_W + 0.289

$$
\text { INO_W - } 1.15 \text { INV_W }
$$

Based on Table 4., it shows that the three independent variables, namely Leadership Competence (KOM), Innovation (INO), Entrepreneurship (WIRA) have a positive influence on performance 
decision variables $(\mathrm{KIN})$ with the value of $0.070,0.000$ and 0.00 . While the investment variable (INV) has no effect on business performance with significance of 0.223 .

\section{Discussion}

1. Competence leader (KOM) has a positive influence on business performance variables $(K I N)$ with a significant value of 0.070 at a significance level of 0.10 .

2. Innovation (INO) has a positive influence on business performance variables (KIN) with a 0.000 significance level at a significant level of 0.05 .

3. Entrepreneurship (WIRA) has a positive influence on business performance variables (KIN) with a synergy value of 0.00 at a significant level of 0.05 .

4. Investment (INV) has no effect on business performance with significance of 0.223.

5. The moderator variables of entrepreneurs have an influence in contributing to the leadership competence of performance. With a significant value of 0.032 .

6. The moderator variables of entrepreneurs have an influence in contributing to innovation on the performance of Entrepreneurship, with a significant value of 0.000 at the 0.05 level

7. The moderator variables of the entrepreneur have no influence in contributing to investment on the performance of the company. with a significant value of 0.060 at the 005 level.

\section{Field Findings}

1. Type of business SMEs in the village of Lontar Tirtayasa District consists of fishermen, nets, seaweed, sea food.

2. In general, the perpetrators of SMEs are very weak in the field of marketing management, finance, production, innovation

3. The perpetrators of SMEs are generally low educated elementary school, junior high school so that the scope of knowledge is very weak in order to develop the business.

4. The perpetrators of SMEs in general trying in the field of SMEs to earn a living family life everyday and derived from hereditary heritage,

5. The perpetrators of SMEs never get information to get capital either in bank loans or revolving funds from the government

6. Production tools to catch fish still using traditional tools such as boats, fingers

7. The perpetrators of SMEs have never received management training from relevant agencies

8. Obstacles faced by the perpetrators of SMEs green shells in the field of marketing of shells obtained every 3 (three) months. The lack of knowledge on how to market the shell is utilized by middlemen who dare to pay first before harvest at a price below market price.

9. Constraints faced by the fishermen, among others, old boats and sometimes leaking, but also the weather that makes the time to go to sea a special constraint.

10. The role of village cooperatives is enough to help the perpetrators of SME although still far from the expectations of SMEs. 


\section{Conclusion}

There is influence of Leadership Competence on Business Performance of SMEs. There is influence of Innovation on Business Performance of SMEs. There is influence of Knowledge Entrepreneurship to Business Performance of SMEs. There is influence of Leadership Competence on Business Performance of SMEs with moderated entrepreneur knowledge. There is influence of Innovation on Business Performance SMEs moderated illmu entrepreneurship chapters. There is no influence of Entrepreneurship Knowledge on Business Performance of SMEs moderated entrepreneurial knowledge. Financial management, marketing and production management training is required for developing SMEs.Information is required to obtain a capital loan or revolving fund for SMEs. Need help marketing SMEs results from related institutions such as green shells and seaweed.

\section{Suggestion}

A SMEs perpetrator requires extensive knowledge such as leadership management, financial management, marketing management, production management and innovation. A SMEs actor is required to be creative in developing products in attracting consumers and enhancing competitiveness.

\section{References}

Berry A., Rodrigoes, E., dan Sandel, H. 2002. Firm and Group Dynamies in The Small and Medium Enterprise Sector in Indonesia. Small Business Economies. Volume 18, pp $141-161$

Best R. 2009 Market Base Management ; Strategy for Growing Consumer Value and Profitability, Pearson Education. Inc, New Jersey.

Doyle P. 2006. Marketing Management and Strategy. Harlow Prentiell Hall, New Jersey

Ferdinand, 2000. Manajemen Pemasaran; Sebuah Pendekatan Strategy , Research

Paper Series No. 01. Program Magister Manajemen Universitas Diponegoro (Maret)

Hughes R.L., Ginnett R.C., Curphy G.J. 2012 Leardeship : Memperkaya Pelajaran Dari Pengalaman Edisi Indonesia, Penerbit Salemba Humanika. Jakarta

Ciptono, WS. 2006. A Seqrential Model of Innovation Strategy - Company Non Financial Performance Links, Gajah Mada International Journal of Bussiness, Vol. 8, No. 2 Yogyakarta.

Ghozali, Imam, 2005. Aplikasi Analisis Multivariate dengan Program SPSS. Badan Penerbit Universitas Diponegoro, Semarang.

Ikka D.R, Cahyono H. 2013. Pengaruh Investasi Dan Tingkat Upah Terhadap Kesempatan

Kerja di Jawa Timur. Jurnal Pendidikan Ekonomi (JUPE) Vo. 1, No. 3, 201, Universitas Negeri Surabaya (UNESA), Surabaya.

Iktriawan, 2005. Analisa Investasi Usaha Kecil Jasa Warnet. Jurnal Manajemen Krida

Wacana. Vol. 5 No. 2 Mei 2005. Universitas Kristen Krida Wacana, Jakarta.

Islamy T. 2014. Pengaruh Investasi dan tenaga Kerja Terhadap Industri Kecil di Surabaya.Jurnal Pendidikan Ekonomi. Vol 3, No. 1, 2014. Universitas Negeri Surabaya, Surabaya.

Kotler P. Dan Keller KL, 2007. Manajemen Pemasaran Edisi Indonesia, INDEKS, Jakarta. 
Raselawati, A (2011). Pengaruh Perkembangan Usaha Kecil Menengah Terhadap Pertumbuhan Ekonomi Pada Sektor UKM di Indonesia Universitas Islam Negeri, Syarif Hidayatullah, FEB, Jakarta

Safina L, Rahayu, SE. 2011. Analisis Pengaruh Investasi Pemerintah Dan swasta TerhadapPenciptaan Kesempatan Kerja di Sumatera Utara Jurnal Manajemen dan Bisnis, Vol 11, No. 1 April 2011, ISSN 1693 - 7610, UMSU.

Sulaksono, A. 2015. Pengaruh Investasi dan tenaga Kerja Terhadap PDB Sektor

Pertambangan Di Indonesia. Jurnal Ekonomi Bisnis, Vol 20 No. 1, April 2015, Universitas Guna Dharma, Jakarta.

Swastawati F. 2012 Studi Kelayakan dan Efisiensi Usaha Pengasapan Ikan Dengan Asap Cair Limbah Pertanian. Jurnal Dinamika Ekonomi Pembangunan, Juli 2011, Vol. 1, No. 1UNDIP.

Swiderski, M. 2002. Soft and conceptual Skill : The aftenOverlochked Components www.Wanfangdata.com. cn/qihan/periodical. Articles/hhl22/2hh12008/0801/08012233 diundah 4 Juni 2016.

Tulus T.H. Tambunan, (2009). "UKM di Indonsia”, Edisi Pertama. Cetakan Pertama, Penerbit Ghalia Indonesia, Bogor.

Vivianie RD., Darminto, Yuningwati F. 2015. Analisis Kelayakan Investasi Usaha Berdasarkan Capital Budgeting Under Risk. (Studi Pada Perusahaan Daerah Air Minum Kabupaten Banyuwangi). Jurnal Administrasi Bisnis (JAB). Vol 26, No. 1, September 2015. 